\title{
The Effects of a High Fat Diet on Chronic Streptozotocin-Diabetic Rats
}

\author{
L. C. A. Baxter and P. J. Schofield \\ School of Biochemistry, University of New South Wales, Kensington, Australia
}

\begin{abstract}
Summary. The effects of a high fat $\operatorname{diet}(30 \%(\mathrm{w} / \mathrm{w})$ corn oil) on chronic streptozotocin-diabetic rats were investigated at the whole body level and at the enzyme level. The diet caused significant decreases in the extent of polydipsia ( $66 \%$ decrease), polyphagia $(49 \%)$, polyuria $(67 \%)$ and glycosuria $(70 \%)$. The activities of selected hepatic enzymes from the glycolytic, gluconeogenic, ureogenic and lipogenic clusters were determined. The fat diet caused significant decreases (range: 47 to $54 \%$ ) in the activity of the ureogenic enzymes carbamyl phosphate synthetase, ornithine transcarbamylase and arginase; had no effect on the glycolytic enzymes glucokinase, hexokinase and pyruvate kinasc; partially decreased the diabetes-induced elevated activities of the gluconeogenic enzymes phosphoenolpyruvate carboxykinase $(63 \%$ decrease), serine dehydratase $(90 \%)$, alanine aminotransferase $(31 \%)$ and aspartate aminotransferase $(65 \%)$, and partially reversed the activity of one lipogenic enzyme, ATP citrate lyase.
\end{abstract}

Key words: Fat diet, streptozotocin, urinary parameters, food consumption, caloric intake, enzymes, glycolysis, gluconeogenesis, ureogenesis, lipogenesis, diabetic rats.

Previous studies in this laboratory using the dietary regime of Patterson et al. [1] demonstrated that a high fat diet containing $30 \%(\mathrm{w} / \mathrm{w})$ corn oil produced a number of beneficial effects, including a reduction in the mortality of diabetic rats, a marked reduction in cataract formation, and an increase in body weight; furthermore a limited study demonstrated a decrease in water intake and decreases in urinary excretion of glucose and urea in diabetic animals maintained on the diet for 120 days [2]. In addition, a very restricted study of the activities of a few hepatic enzymes of diabetic rats fed the corn oil diet for 106 days suggested that there were changes in the activities of some hepatic enzymes consequent to the feeding of the fat diet [2].

The aim of this work was to evaluate the effects of the corn oil diet on hepatic enzymes and on urinary parameters in diabetic rats. The dietary conditions were those of Patterson et al. [2] i. e. a 30\% corn oil diet fed ad lib, in view of the beneficial effects ensuing from this particular dietary regime [1]. No attempt was made to use other dietary conditions such as pair feeding or isocaloric diets since such conditions would distort the real effects demonstrated by Patterson et al. [1] and subsequently confirmed by Hutton et al. [2].

\section{Materials and Methods}

\section{Diets}

A fat diet was prepared which was similar in nutrient composition to that used by Patterson et al. [1]. Dog meal (K9 Kennel Mcal; Carnation Pty. Ltd., Sydney, Australia) was pulverised and mixed with corn oil (Vegetable Oils Pty. Ltd., Sydney, Australia) and an aqueous solution (at $60^{\circ} \mathrm{C}$ ) of gelatin (Davis Gelatin Pty. Ltd., Sydney, Australia). The mixture was cut into pieces (approximately $8 \mathrm{~cm}$ cubes) and stored at $-20^{\circ} \mathrm{C}$. The proportions of the ingredients in the diet (dry weight basis) were $67 \%$ dog meal, $30 \%$ corn oil and $3 \%$ gelatin. The nutrient composition is shown in Table 1. The standard diet was Allied Rat and Mouse Kubes (Allied Feeds, Sydney, Australia). Both the dog meal and the rat cubes contained salts and vitamins (A, D and E); neither manufacturer would supply precise information on the composition of the salt and vitamin components.

\section{Experimental Procedures}

Wistar rats (initial body weight $(200-220 \mathrm{~g})$ were obtained from the Animal Breeding Unit, Prince Henry Hospital, Sydney, Australia. Diabetes was induced in the animals with a single 
intraperitoneal injection of streptozotocin (Upjohn \& Co., Kalamazoo, U. S. A.) $(40 \mathrm{mg} / \mathrm{ml}$ in $0.1 \mathrm{~mol} / 1$ phosphate $/ 0.4 \mathrm{~mol} / \mathrm{l}$ citrate buffer, $\mathrm{pH} 6.5$ ) at a dose of $65 \mathrm{mg} / \mathrm{kg}$ body wt. one month before starting the dietary treatment. The animals had free access to water at all times and were fed ad lib. Diagnosis of diabetes was

Table 1. Composition of the diets

\begin{tabular}{lll}
\hline & $\begin{array}{l}\text { Standard diet } \\
(\mathrm{g} / 100 \mathrm{~g})\end{array}$ & $\begin{array}{l}\text { Fat diet } \\
(\mathrm{g} / 100 \mathrm{~g})\end{array}$ \\
\hline Carbohydrate & 65.2 & 45.2 \\
Protein & 23.0 & 16.4 \\
Fat & 5.0 & 34.4 \\
Crude fibre & 6.0 & 3.3 \\
Salt & 0.8 & 0.7 \\
\hline
\end{tabular}

established $48 \mathrm{~h}$ after the streptozotocin injection by determination of the tail vein blood glucose concentration [3], and by testing freshly voided urine samples from each animal for glucose (Labstix; Ames \& Co., Mulgrave, Victoria, Australia). Any streptozotocin-treated animal which at this time had a 4 to 6 h-fasting blood glucose concentration of less than $14.0 \mathrm{mmol} / 1$, or in which glycosuria was not present, was eliminated from the study.

For the determination of urinary excretion of glucose and urea, animals were individually housed in metabolism cages and their urine was collected for a $24 \mathrm{~h}$ period on 3 consecutive days. The volume of urine voided by each animal was recorded, and samples were taken for the determination of glucose and urea. Separate groups of animals were used for the urinary parameters, for the consumption studies, and for the enzyme assays.

For the determination of daily food consumption and increase in body weight per animal, measurements were taken at 3 day intervals. It was imperative to measure body weight of the animals at the same time of the day $(14.00 \mathrm{~h})$, since the weight of the

Table 2. Effect of the standard diet and high fat diet on water intake and urinary parameters in streptozotocin-diabetic rats

\begin{tabular}{|c|c|c|c|c|c|c|}
\hline \multirow[b]{2}{*}{ Duration of diet } & \multirow[t]{2}{*}{ Standard diet } & \multicolumn{2}{|l|}{ High fat diet } & \multicolumn{3}{|l|}{ Standard diet } \\
\hline & & 2 weeks & 3 weeks & 1 week & 2 weeks & \\
\hline Water intake $(\mathrm{ml} / 24 \mathrm{~h})$ & $117 \pm 32^{b}$ & $50 \pm 17^{\mathrm{a}}$ & $41 \pm 20^{\mathrm{a}}$ & $112 \pm 31^{\mathrm{b}}$ & $132 \pm 45^{\mathrm{c}}$ & $F_{4,94}=93^{* *}$ \\
\hline Urine volume $(\mathrm{ml} / 24 \mathrm{~h})$ & $92 \pm 29^{b}$ & $36 \pm 14^{\mathrm{a}}$ & $31 \pm 16^{\mathrm{a}}$ & $91 \pm 27^{b}$ & $114 \pm 40^{c}$ & $F_{4,94}=103 * *$ \\
\hline Glucose excretion $(\mathrm{g} / 24 \mathrm{~h})$ & $5.4 \pm 1.4^{\mathrm{b}}$ & $2.0 \pm 0.6^{\mathrm{a}}$ & $1.5 \pm 0.5^{\mathrm{a}}$ & $6.0 \pm 1.5^{\mathrm{b}}$ & $10.0 \pm 2.2^{\mathrm{c}}$ & $\mathrm{F}_{4,94}=184 * *$ \\
\hline Urea excretion $(g / 24 h)$ & $0.63 \pm 0.26^{\mathrm{b}}$ & $0.27 \pm 0.06^{\mathrm{a}}$ & $0.33 \pm 0.08^{\mathrm{a}}$ & $0.88 \pm 0.20^{\mathrm{c}}$ & $1.77 \pm 0.32^{\mathrm{d}}$ & $F_{4,94}^{*, 94}=195^{* * *}$ \\
\hline Blood glucose $(\mathrm{mmol} / \mathrm{l})$ & $17.0 \pm 1.3$ & $15.6 \pm 3.0$ & & & & n. s. \\
\hline
\end{tabular}

The animals were maintained on the standard diet for 8 weeks to obtain basal values. The animals were then fed the fat diet, and water intake and urinary parameters determined after 2 weeks and 3 weeks on the fat diet. The fat diet was then replaced by the standard diet, and the parameters redetermined at weekly intervals for a further 2 weeks. In all cases, the animals were fed ad lib. In each case, the value is the mean value determined over a 3 day period of daily testing. The values are expressed as mean $\pm \operatorname{SD}(n=7)$. For the $F$ test, the $F$ ratio was highly significant $(* *=\mathrm{P}<0.01$; n. $\mathrm{s}$. $=$ not significant). The values with different superscripts are significantly different $(\mathrm{P}<0.05)$ using Duncan's Multiple Range Test [17]

The blood glucose values ( 4 to $6 \mathrm{~h}$ fasting values) were determined after 6 weeks on the initial standard diet, and after 2 weeks on the fat diet. At the completion of the feeding trial, lenticular opacities of varying severity were present in all animals

Table 3. The effect of the standard diet and high fat diet on food consumption in normal and streptozotocin-diabetic rats

\begin{tabular}{|c|c|c|c|c|c|}
\hline & $\begin{array}{l}\text { Normal } \\
\text { Standard diet } \\
(\mathrm{n}=38)\end{array}$ & $\begin{array}{l}\text { High fat diet } \\
(\mathrm{n}=9)\end{array}$ & $\begin{array}{l}\text { Diabetic } \\
\text { Standard diet } \\
(\mathrm{n}=39)\end{array}$ & $\begin{array}{l}\text { High fat diet } \\
(\mathrm{n}=12)\end{array}$ & \\
\hline Food consumption $(\mathrm{g} / 24 \mathrm{~h})$ & $22.0 \pm 1.2^{b}$ & $15.5 \pm 0.3^{\mathrm{a}}$ & $41.6 \pm 1.8^{\mathrm{c}}$ & $21.1 \pm 1.2^{b}$ & $F_{3,26}=635^{* *}$ \\
\hline Body weight (g) & $241 \pm 22^{a}$ & $247 \pm 19^{a}$ & $227 \pm 42^{\mathrm{a}}$ & $245 \pm 54^{a}$ & n. s. \\
\hline$\frac{\text { Food consumption }(\mathrm{g} / 24 \mathrm{~h})}{\text { Body weight }(\mathrm{g})} \times 100 \%$ & $10.8 \pm 0.9^{c}$ & $6.7 \pm 0.2^{\mathrm{a}}$ & $18.2 \pm 0.5^{\mathrm{d}}$ & $8.9 \pm 0.7^{b}$ & $\mathrm{~F}_{3,26}=526 * *$ \\
\hline Carbohydrate intake $(\mathrm{g} / 24 \mathrm{~h})$ & $14.4 \pm 0.8^{\mathrm{c}}$ & $7.0 \pm 0.1^{\mathrm{a}}$ & $27.2 \pm 1.1^{\mathrm{d}}$ & $9.6 \pm 0.6^{\mathrm{b}}$ & $F_{3,26}=947 * *$ \\
\hline Protein intake $(\mathrm{g} / 24 \mathrm{~h})$ & $5.1 \pm 0.3^{\mathrm{c}}$ & $2.5 \pm 0.1^{\mathrm{a}}$ & $9.6 \pm 0.4^{\mathrm{d}}$ & $3.5 \pm 0.2^{\mathrm{b}}$ & $F_{3,26}=923^{* *}$ \\
\hline Fat intake $(\mathrm{g} / 24 \mathrm{~h})$ & $1.1 \pm 0.1^{\mathrm{a}}$ & $5.3 \pm 0.1^{\mathrm{c}}$ & $2.1 \pm 0.1^{\mathrm{b}}$ & $7.3 \pm 0.4^{\mathrm{d}}$ & $\mathrm{F}_{3,26}=1568^{* *}$ \\
\hline Food consumption (kcal/24 h) & $87.7 \pm 4.9^{\mathrm{a}}$ & $86.1 \pm 1.7^{\mathrm{a}}$ & $165.7 \pm 7.0^{\mathrm{c}}$ & $117.4 \pm 6.8^{b}$ & $F_{3,26}^{3,20}=387 * *$ \\
\hline Carbohydrate intake (kcal/24 h) & $57.4 \pm 3.2^{\mathrm{c}}$ & $28.0 \pm 0.6^{\mathrm{a}}$ & $108.6 \pm 4.6^{\mathrm{d}}$ & $38.2 \pm 2.2^{\mathrm{b}}$ & $F_{3,26}=947 * *$ \\
\hline Protein intake $(\mathrm{kcal} / 24 \mathrm{~h})$ & $20.3 \pm 1.1^{\mathrm{c}}$ & $10.2 \pm 0.2^{\mathrm{a}}$ & $38.3 \pm 1.6^{\mathrm{d}}$ & $13.9 \pm 0.8^{b}$ & $F_{3,26}=923^{* *}$ \\
\hline Fat intake (kcal/24 h) & $9.9 \pm 0.6^{\mathrm{a}}$ & $47.9 \pm 1.0^{\mathfrak{c}}$ & $18.7 \pm 0.8^{b}$ & $65.4 \pm 3.8^{\mathrm{d}}$ & $\mathrm{F}_{3,26}=1568^{* *}$ \\
\hline
\end{tabular}

Normal animals were maintained on the high fat diet for 30 days. Diabetic animals were maintained on the standard diet for 50 days. For a separate subgroup of the same diabetic animals, the high fat diet was introduced 28 days after the induction of diabtes, and maintained for 30 days. The food consumption was determined every third day for the last 30 days of dietary treatment in each group. Values are expressed as mean $\pm \mathrm{SD}$. For the $\mathrm{F}$ test, the $\mathrm{F}$ ratio was highly significant (** $=\mathrm{P}<0.01 ; \mathrm{n}$. $\mathrm{s}$. = not significant). Those values with different superscripts are significantly different $(\mathrm{P}<0.05)$ using Duncan's Multiple Range Test [17] 
diabetic animals fed the standard diet fluctuated approximately $10 \mathrm{~g}$ every $24 \mathrm{~h}$ due to their polydipsia. This precaution was found to be unnecessary in the measurement of daily food consumption.

\section{Analytical Procedures}

Glucose in urine samples was determined by the glucose-oxidase method [3] and urea by the method of Beale \& Croft [4]. The rates of excretion of glucose and urea were calculated from these determinations.

For the determination of enzyme activities the animals were sacrificed at approximately $10.00 \mathrm{~h}$ and the liver immediately removed. A portion of the liver was weighed (approximately $1 \mathrm{~g}$ ), and then for all enzymes other than the urea cycle enzymes homogenized (Potter-Elvehjem homogeniser) in 9 volumes of an ice-cold buffered salt solution $(0.15 \mathrm{~mol} / 1 \mathrm{KC} 1,0.05 \mathrm{~mol} / \mathrm{l}$ $\mathrm{KHCO}_{3}, 0.006 \mathrm{~mol} / \mathrm{l}$ disodium ethylenediamine tetraacetate, $\mathrm{pH}$ 7.4). Samples of the homogenate were retained for the determination of protein [5]. For the assay of the urea cycle enzymes, the homogenizing medium was 9 volumes of $1 \mathrm{~g} / 1$ cetyltrimethylammonium bromide, added at room temperature. The remaining homogenate was subjected to centrifugation $(30000 \mathrm{~g}$ for $10 \mathrm{~min}$ at $0{ }^{\circ} \mathrm{C}$ ) and samples of the supernatant fraction were used for the determination of the activities of all enzymes, except glucose 6phosphatase (EC 3.1.3.9) (1000 g for $10 \mathrm{~min}$ at $0^{\circ} \mathrm{C}$ ), aspartate aminotransferase (EC 2.6.1.1) (liver frozen at $-20^{\circ} \mathrm{C}$ for 2.5 days and the homogenate then centrifuged at $1000 \mathrm{~g}$ for $10 \mathrm{~min}$ at $0^{\circ} \mathrm{C}$ ) and the urea cycle enzymes (centrifuged at $10000 \mathrm{~g}$ for $15 \mathrm{~min}$ at $0^{\circ} \mathrm{C}$ ).

Cytoplasmic alanine aminotransferase (EC 2.6.1.2) and total aspartate aminotransferase (EC 2.6.1.1) were estimated by the method of Hatch and Shaio-Lim Mau [6]. ATP citrate lyase (EC 4.1.3.8) was estimated by a modified version of the method of Srere [7]: the assay medium contained $80 \mathrm{mmol} / 1$ triethanolamine, $\mathrm{pH} 7.5 ; 4 \mathrm{mmol} / 1 \mathrm{MgCl}_{2} ; 4 \mathrm{mmol} / 1 \mathrm{ATP}, \mathrm{pH} 7.5 ; 0.8 \mathrm{mmol} / 1 \mathrm{mer}-$ captoethanol; $0.1 \mathrm{mmol} / 1 \mathrm{CoA} ; 0.25 \mathrm{mmol} / 1 \mathrm{NADH} ; 9 \mathrm{U}$ of malate dehydrogenase; $10 \mathrm{mmol} / 1$ potassium-citrate, $\mathrm{pH} 7.5$; and $0.1 \mathrm{ml}$ supernatant, in a total volume of $2.5 \mathrm{ml}$. The reaction was initiated by the addition of citrate.

Fructose 1, 6-bisphosphatase (EC 3.1.3.11) was estimated by the method of Zalitis [8]. Glucokinase (EC 2.7.1.2) and hexokinase (EC 2.7.1.1) were estimated by the method of Sharma et al. [9]. Glucose 6-phosphate dehydrogenase (EC 1.1.1.49) and 6phosphogluconate dehydrogenase (EC 1.1.1.44) were estimated by a modified version of the method of Glock and McLean [10]: the assay medium contained $100 \mathrm{mmol} / 1$ Tris $\mathrm{HC} 1, \mathrm{pH} 7.4$; $10 \mathrm{mmol} / 1 \mathrm{MgCl}_{2} ; 1 \mathrm{mmol} / \mathrm{I} \mathrm{NADP}$ and either $5 \mathrm{mmol} / 1$ glucose 6 phosphate (G6P) or $5 \mathrm{mmol} / 1$ 6-phosphogluconate (6PG); and $0.1 \mathrm{ml}$ supernatant, in a total volume of $1.0 \mathrm{ml}$. The reaction was initiated by the addition of G6P or 6PG. Glucose 6-phosphatase (EC 3.1.3.9) was estimated by the method of Yeung et al. [11]. Malate dehydrogenase (decarboxylating) (NADP) (EC 1.1.1.40) was estimated by the method of Ochoa [12]. PEP carboxykinase (EC 4.1.1.32) was estimated by the method of Ballard and Hanson [13]. Pyruvate kinase (EC 2.7.1.40) was estimated by a modified version of the method of Irving and Williams [14]: the assay medium contained $100 \mathrm{mmol} / 1$ Tris $\mathrm{HCl}, \mathrm{pH} 7.4 ; 10 \mathrm{mmol} / \mathrm{l}$ $\mathrm{MgCl}_{2} ; 3 \mathrm{mmol} / 1 \mathrm{ADP} ; 0.3 \mathrm{mmol} / 1 \mathrm{NADH} ; 2.6 \mathrm{U}$ of lactate dehydrogenase; $4 \mathrm{mmol} / \mathrm{l}$ phosphoenolpyruvate (PEP); and $0.01 \mathrm{ml}$ supernatant, in a total volume of $1.0 \mathrm{ml}$. The reaction was initiated by the addition of PEP. Serine dehydratase (EC 4.2.1.13) was estimated by a modified version of the method of Freedland and Avery [15]: the assay medium contained $20 \mathrm{mmol} / 1$ potassium phosphate buffer, $\mathrm{pH} 8.0 ; 0.2 \mathrm{mmol} / 1$ pyridoxal phosphate; $0.15 \mathrm{mmol} / 1 \mathrm{NADH} ; 1.3 \mathrm{U}$ of lactate dehydrogenase; $80 \mathrm{mmol} / \mathrm{l}$ L-serine, $\mathrm{pH} 8.0$; and $0.2 \mathrm{ml}$ supernatant, in a total volume of
$1.0 \mathrm{ml}$. The reaction was initiated by the addition of L-serine. Carbamyl phosphate synthetase (EC 2.7.2.5), ornithine transcarbamylase (EC 2.1.3.3) and arginase (EC 3.5.3.10) were estimated by the method of Brown and Cohen [16]. All determinations were carried out at $30^{\circ} \mathrm{C}$, except for glucose 6-phosphatase, PEP carboxykinase and the urea cycle enzymes $\left(37^{\circ} \mathrm{C}\right)$.

\section{Statistics}

All statistical analyses of results were performed by analysis of variance. A one-way analysis of variance was used in all cases except the time course experiment, which involved the measurement of the water intake and some urinary excretion parameters of a group of diabetic animals fed the standard diet first, then the fat diet, and then returned to the standard diet. Since the same 7 animals were used throughout this experiment, it is feasible that any one of these animals could cause a systematic change capable of distorting the result. Thus, to eliminate any non-random rat effect, a two-way analysis of variance was performed. It was assumed that no one animal would be at an advantage or disadvantage when on a particular dietary regimen. An F test was used to determine whether one or more of the differences among means was significant, and if the F ratio was significant, the Duncan's Multiple Range Test was used to decide which of the differences were significant, at the $5 \%$ level of probability [17].

\section{Results}

\section{Whole Body Parameters}

Animals (initial weight of approximately $210 \mathrm{~g}$ ) which were maintained in an untreated diabetic state on the standard diet showed signs of dehydration, polyuria and wasting, with the fat deposits severely depleted within 3 weeks. After transferral to the fat diet, the general condition of the animals improved, to such an extent that within 3 weeks the increase in body weight (approximately 6-7 g/week) was in the same range as that of normal animals on either the standard diet or the fat diet (approximately $7-8 \mathrm{~g}$ / week). There was no significant difference in the 4 to 6 hour-fasted blood glucose concentrations of the diabetic animals on either the standard diet before the introduction of the fat diet, or on the high fat diet, the respective values being $17.0 \pm 1.3 \mathrm{mmol} / \mathrm{l}$ and $15.6 \pm 3.0 \mathrm{mmol} / \mathrm{l}$. Other studies in this laboratory have consistently shown that the blood glucose level of diabetic animals fed the fat diet is always 8 to $13 \%$ less than that for matched groups of diabetic animals on the standard diet, the range of levels being $13-18 \mathrm{mmol} / 1$ and $17-21 \mathrm{mmol} / 1$ respectively (unpublished results). After 3 weeks on the corn oil diet, both the daily water intake and the urine volume of the diabetic animals decreased by $66 \%$ compared to the values obtained previously for the same animals on the standard diet (Table 2). Within 2 weeks of reverting to the standard diet, the diabetic animals consumed even more water than previously 
Table 4. The effect of the standard diet and high fat diet on the activities (IU/g) of some urea cycle enzymes in the liver of normal and streptozotocin-diabetic rats

\begin{tabular}{lcclcl}
\hline & Normal & & Diabetic & \\
\cline { 2 - 6 } & $\begin{array}{l}\text { Standard diet } \\
(\mathrm{n}=3)\end{array}$ & $\begin{array}{l}\text { High fat diet } \\
(\mathrm{n}=3)\end{array}$ & $\begin{array}{l}\text { Standard diet } \\
(\mathrm{n}=6)\end{array}$ & $\begin{array}{l}\text { High fat diet } \\
(\mathrm{n}=6)\end{array}$ \\
\hline Carbamyl phosphate synthetase & $4.1 \pm 2.3^{\mathrm{a}}$ & $4.4 \pm 0.9^{\mathrm{a}}$ & $10.1 \pm 1.8^{\mathrm{b}}$ & $5.4 \pm 1.1^{\mathrm{a}}$ & $\mathrm{F}_{3,14}=16.05^{* * *}$ \\
Ornithine transcarbamylase & $294 \pm 62^{\mathrm{b}}$ & $170 \pm 21^{\mathrm{a}}$ & $299 \pm 30^{\mathrm{b}}$ & $139 \pm 36^{\mathrm{a}}$ & $\mathrm{F}_{3,16}=21.46^{* *}$ \\
Arginase & $344 \pm 43^{\mathrm{a}}$ & $249 \pm 58^{\mathrm{a}}$ & $729 \pm 220^{\mathrm{b}}$ & $388 \pm 72^{\mathrm{a}}$ & $\mathrm{F}_{3,14}=10.65^{* * *}$ \\
Liver weight $(\mathrm{g})$ & $9.2 \pm 1.1^{\mathrm{a}}$ & $8.7 \pm 1.2^{\mathrm{a}}$ & $12.4 \pm 2.5^{\mathrm{b}}$ & $10.1 \pm 0.9^{\mathrm{a}}$ & $\mathrm{F}_{3,17}=5.64^{*}$ \\
\hline
\end{tabular}

Normal animals were maintained on the high fat diet for 4 weeks. Diabetic animals were maintained on the standard diet for 8 weeks. The high fat diet was introduced to a separate subgroup of the same group of diabetic animals 28 days after the induction of diabetes, and the high fat diet maintained for 5 weeks. Those values with different superscripts are significantly different $(* \mathrm{P}<0.05)$ using Duncan's Multiple Range Test [17]. The values are expressed as mean \pm SD, and the statistical analysis is the same as described in Tables 2 and 3

Table 5. The effect of the standard diet and high fat diet on the activities (IU/g) of some key hepatic enzymes in normal and streptozotocindiabetic rats

\begin{tabular}{|c|c|c|c|c|c|}
\hline & \multicolumn{2}{|l|}{ Normal } & \multicolumn{2}{|l|}{ Diabetic } & \\
\hline & $\begin{array}{l}\text { Standard diet } \\
(\mathrm{n}=6)\end{array}$ & $\begin{array}{l}\text { High fat diet } \\
(\mathrm{n}=6)\end{array}$ & $\begin{array}{l}\text { Standard diet } \\
(\mathrm{n}=5)\end{array}$ & $\begin{array}{l}\text { High fat diet } \\
(\mathrm{n}=5)\end{array}$ & \\
\hline Alanine aminotransferase & $19.6 \pm 4.8^{\mathrm{a}}$ & $16.9 \pm 3.8^{\mathrm{a}}$ & $39.6 \pm 7.6^{\mathrm{c}}$ & $27.9 \pm 3.0^{\mathrm{b}}$ & $\mathrm{F}_{3,16}=17.91^{* *}$ \\
\hline Aspartate aminotransferase & $90.5 \pm 19.6^{b}$ & $59.4 \pm 15.1^{\mathrm{ab}}$ & $154.3 \pm 47.9^{\mathrm{c}}$ & $55.7 \pm 9.2^{\mathrm{a}}$ & $F_{3,19}^{3,16}=16.57 * *$ \\
\hline Fructose 1,6 -biphosphatase & $5.3 \pm 1.2^{\mathrm{a}}$ & $6.3 \pm 0.57^{\mathrm{a}}$ & $6.0 \pm 0.28^{a}$ & $6.5 \pm 0.21^{\mathrm{a}}$ & n. $\mathrm{S}$. \\
\hline Glucose 6-phosphatase & $11.0 \pm 1.6^{\mathrm{a}}$ & $11.2 \pm 1.9^{\mathrm{a}}$ & $17.0 \pm 5.2^{\mathrm{b}}$ & $22.8 \pm 2.5^{\mathrm{c}}$ & $F_{3,17}=12.37^{* *}$ \\
\hline Phosphoenolpyruvate carboxykinase & $1.51 \pm 0.41^{\mathrm{a}}$ & $0.51 \pm 0.14^{\mathrm{a}}$ & $4.80 \pm 1.53^{\mathrm{b}}$ & $1.81 \pm 0.31^{\mathrm{a}}$ & $F_{3,20}=25.05^{* *}$ \\
\hline Serine dehydratase & $1.58 \pm 0.96^{\mathrm{a}}$ & $0.48 \pm 0.23^{\mathrm{a}}$ & $17.83 \pm 9.13^{\mathrm{b}}$ & $1.63 \pm 1.56^{\mathrm{a}}$ & $\mathrm{F}_{3,26}^{3,20}=33.24 * *$ \\
\hline ATP citrate lyase & $1.04 \pm 0.07^{\circ}$ & $0.43 \pm 0.08^{b}$ & $0.27 \pm 0.05^{\mathrm{a}}$ & $0.39 \pm 0.09^{b}$ & $\mathrm{~F}_{3,18}^{3,26}=90.41^{* *}$ \\
\hline Malate dehydrogenase (decarboxy- & & & & & \\
\hline lating NADP) & $0.98 \pm 0.37^{b}$ & $1.69 \pm 0.51^{\mathrm{c}}$ & $0.14 \pm 0.02^{\mathrm{a}}$ & $0.50 \pm 0.08^{\mathrm{ab}}$ & $\mathrm{F}_{3,12}=13.47^{* *}$ \\
\hline Glucose 6-phosphate dehydrogenase & $1.44 \pm 0.55^{b}$ & $1.52 \pm 0.59^{b}$ & $0.75 \pm 0.18^{\mathrm{a}}$ & $1.09 \pm 0.28^{\mathrm{ab}}$ & $\mathrm{F}_{3,23}=4.01^{*}$ \\
\hline 6-Phosphogluconate dehydrogenase & $0.90 \pm 0.24^{\mathrm{b}}$ & $1.07 \pm 0.51^{b}$ & $0.47 \pm 0.13^{\mathrm{a}}$ & $0.53 \pm 0.09^{\mathrm{a}}$ & $\mathrm{F}_{3,19}=6.09 * *$ \\
\hline Hexokinase & $0.26 \pm 0.07^{\mathrm{a}}$ & $0.32 \pm 0.04^{\mathrm{a}}$ & $0.16 \pm 0.04^{\mathrm{a}}$ & $0.29 \pm 0.14^{\mathrm{a}}$ & n.s. \\
\hline Glucokinase & $1.59 \pm 0.33^{\mathrm{c}}$ & $1.14 \pm 0.30^{\mathrm{b}}$ & $0.071 \pm 0.002^{\mathrm{a}}$ & $0.15 \pm 0.05^{\mathrm{a}}$ & $\mathrm{F}_{3,17}=44.49^{* * *}$ \\
\hline Pyruvate kinase & $33.1 \pm 12.0^{\mathrm{b}}$ & $11.0 \pm 3.8^{\mathrm{a}}$ & $11.8 \pm 1.1^{\mathrm{a}}$ & $6.5 \pm 1.8^{\mathrm{a}}$ & $\mathrm{F}_{3,21}=20.18^{*}$ \\
\hline
\end{tabular}

The experimental conditions are the same as those described in Table 4 . The values are expressed as mean \pm SD; values with different superscripts are significantly different $(\mathrm{P}<0.05)$. The statistical analyses are the same as those described in Table $3 ;(*=\mathrm{P}<0.05)$ indicates a significant $F$ ratio

on the standard diet, and a larger volume of urine was excreted.

The daily rate of excretion of glucose and urea by the diabetic animals 3 weeks after they had commenced the corn oil diet decreased by $70 \%$ and $30 \%$ respectively compared with the previous diet (Table 2). Within 2 weeks of reverting to the standard diet, the daily excretion rates of glucose and urea increased to levels well above the pretreatment values (Table 2). Values for the daily water consumption and rates of glucose and urea excretion of normal animals on either diet were in agreement with previously reported values [2].

The food consumption ( $\mathrm{g} /$ day) of normal animals on the corn oil diet decreased by $30 \%$ compared with that on the standard diet. As a result, the daily caloric intake for normal animals on either diet was virtually the same (Table 3). Diabetic animals exhibited polyphagia, consuming twice as much of the standard diet as did the normal animals, thus receiving twice the normal total daily caloric intake. However, diabetic animals on the fat diet ate less food per day, the total daily caloric intake being only 1.3 fold greater than that of normal animals on either diet. The decreased consumption of the fat diet, compared with that of the standard diet, was not due to a taste aversion. When diabetic animals were confronted with a free choice of both standard and fat diet, the average total daily food consumption was $23 \mathrm{~g}$, consisting of $14 \mathrm{~g}$ of fat diet and $9 \mathrm{~g}$ of standard diet; no conditioning period was required. Under these conditions, the total caloric intake was approximately 
$120 \mathrm{kcal} /$ day, which is similar to that for the fat diet alone. Previous experience in this laboratory demonstrated that introduction of the high fat diet within 2 weeks of the induction of diabetes resulted in the death of all the animals within 2 to 3 days, with massive ketonuria being a characteristic feature (unpublished results). However, the introduction of the fat diet 4 weeks or more after streptozotocin treatment completely averted this problem, with chronic diabetic animals on either the standard diet or the fat diet subsequently showing negligible levels of ketonuria.

\section{Enzyme Activities}

For the urea cycle enzymes studied, in normal animals the activities of carbamyl phosphate synthetase and arginase were not affected by the fat diet while that of ornithine transcarbamylase was decreased by about $40 \%$ (Table 4 ). In diabetic animals on the standard diet, the activities of carbamyl phosphate synthetase and arginase were increased 2-3 fold compared to normal animals. In diabetic animals, the corn oil diet had the effect of reducing the activities of all 3 enzymes by approximately $50 \%$.

The activities of enzymes from the glycolytic, gluconeogenic and lipogenic clusters, and some associated enzymes, were determined for both normal and diabetic animals on the standard and fat diets (Table 5).

In normal animals, the fat diet had no effect on the activities of the gluconeogenic enzymes. In the diabetic animals fed the standard diet, the activities of all gluconeogenic enzymes, except fructose 1,6bisphosphatase, were increased. However, in the diabetic animals fed the fat diet, the elevated activities of all the enzymes except glucose 6-phosphatase were decreased.

For the lipogenic enzymes, the fat diet resulted in a decrease in the activity of ATP citrate lyase and an increase in the activity of malate dehydrogenase (decarboxylating) in the normal animals. There was no effect on glucose 6-phosphate dehydrogenase and 6-phosphogluconate dehydrogenase. In the diabetic animals fed the standard diet, all four enzymes showed decreased activities. On the fat diet, this trend was partially reversed for ATP citrate lyase; the activities of the three other enzymes were not, however, significantly changed.

Of the glycolytic enzymes, the activities of glucokinase and pyruvate kinase in the normal animals fed the fat diet were decreased. In the diabetic animals fed the standard diet, the activity of these two enzymes was decreased, and these changes were not affected by the fat diet.

\section{Discussion}

For diabetic animals maintained on the fat diet for 3 weeks, the $65 \%$ decrease in carbohydrate intake, compared with that for the standard diet, correlates well with the $70 \%$ decrease in urinary glucose excretion. Similarly, the $30 \%$ decrease in urinary urea excretion is consistent with the decrease $(64 \%)$ in protein intake. The above data are in agreement with a large number of values independently obtained in this laboratory and which have consistently demonstrated that the fat diet causes a $60-65 \%$ decrease in carbohydrate intake; $60-70 \%$ decrease in glucose excretion; $50-65 \%$ decrease in protein intake and $30-50 \%$ decrease in urea excretion (unpublished results). The decreased carbohydrate intake and excretion is presumably the major cause for the concurrent decrease in polydipsia and polyuria, thus decreasing metabolic demands on renal function. The fact that the blood glucose level is only marginally reduced by the fat diet, whereas the glucose excretion is considerably decreased, suggests that the principal effect is an overall decrease in the glucose flux without a concomitant alleviation of the hyperglycaemia. In the case of protein, the decreased dietary intake would decrease the amount of $\alpha$-amino nitrogen which would need to be excreted as urea. The enzyme data are consistent with this situation, insofar as the activity of the urea cycle enzymes decreased in the diabetic animals on the fat diet compared to those maintained on the standard diet.

The activities of the enzymes recorded in Table 5 for diabetic animals on the standard diet are in the same range as generally reported [18-23]. However, the activities of the enzymes for normal animals on the fat diet (Table 5) are not in complete agreement with reported values. This is not surprising as there are many inconsistencies within the literature.

In general, the experimental fat diets reported in the literature are of two types: (i) those that contain no carbohydrate, and (ii) those that contain varying amounts of carbohydrate. There is reasonable agreement that the activities of glucokinase and pyruvate kinase decrease when normal animals are given a fat diet containing no carbohydrate $[24,25,26]$. When the animals are given a fat diet containing carbohydrate the activities of these two enzymes either decrease or remain constant $[27,28]$.

Our results confirm the latter findings, in that in the normal animals the fat diet resulted in decreases in the activity of glucokinase and pyruvate kinase. The fat diet had no effect on the activity of these two enzymes in the diabetic animals. The continued depressed activity of glucokinase in the diabetic animals compared to that in the normal animals is con- 
sistent with the fact that the insulin levels in the diabetic animals maintained on either diet remained at very low levels (unpublished results).

For the gluconeogenic enzymes, there are variations when the activities of these enzymes, particularly glucose 6-phosphatase, are considered in relation to the fat diets used $[25,26]$. In normal animals, the fat diet caused a decrease in carbohydrate caloric intake from $65 \%$ of the total caloric intake on the standard diet to $33 \%$. This decrease had no effect on the activity of the gluconeogenic enzymes. In the diabetic animals the fat diet partially reversed the diabetes-induced increases in the activity of key gluconeogenic enzymes. The tendency for increased glucose 6-phosphatase activity in diabetic animals on a fat diet is consistent with previous findings [29]. The unchanging activity of fructose 1,6-bisphosphatase in the above dietary and hormonal conditions is also consistent with previous reports [25].

Fat diets have previously been demonstrated to have a variety of effects on the activity of lipogenic enzymes in normal animals, with the extent of desaturation of the fat appearing to be an important factor; the decrease in the activity of ATP citrate lyase in normal animals on the corn oil diet is consistent with previous findings $[27,28,30]$. However, for the other lipogenic enzymes, feeding of unsaturated fat diets of various compositions have resulted in diverse changes in enzyme activities [24, 27, 30-32]. Since unsaturated fat diets, such as a corn oil diet, clearly do not result in a uniform spectrum of changes in lipogenic enzyme activities in normal animals, the effect of the diet in diabetic animals would be expected to be complex, particularly in view of the diabetes-induced decrease in fatty acid desaturase capacity [33]. In the diabetic animals on the standard diet, the activity of all the lipogenic enzymes studied was depressed. Mobilisation of fat depots during the initial ketotic stage, combined with decreased lipogenesis, resulted in complete depletion of endogenous fat. The enzymic data are consistent with these changes. Feeding of the fat diet partially reversed one of these enzyme changes. Although even after only 3 weeks on the fat diet the diabetic animals regained lipid depots, such as mesenteric fat, this increased lipid deposition is probably due to dietary fat deposition, rather than de novo lipogenesis, since fatty acid biosynthesis in these animals remained depressed (unpublished results).

Thus, in general, the effect of the fat diet in the diabetic animals is to partially reverse some of the diabetes-induced enzyme changes. These changes are manifested at the whole body level by changes in body parameters and in urinary parameters. It appears that the primary effect is dietary i. e. a reduc- tion in dietary carbohydrate and protein, and an increase in dietary fat. This is consistent with the situation that in the absence of insulin, the caloric contribution from carbohydrate is reduced, and the increased amount of unsaturated dietary fat is more able to satisfy the energy requirements than is dietary carbohydrate. These changes in the profile of energy metabolism particularly with respect to glucose status, then provide a variety of beneficial effects, e. g. decreases in polyuria and polydipsia which presumably moderate the detrimental additional metabolic demands of the frank diabetic state. The net result of the effect of the fat diet is to allow the development of a new, albeit fragile, steady state which is characterised by the changes cited above, and by decreased mortality rates and incidence of diabetic cataractogenesis as previously reported [2].

Acknowledgements. We thank Upjohn and Co. for the gift of streptozotocin.

\section{References}

1. Patterson JW, Patterson ME, Everett-Kinsey V, Reddy DVN (1965) Lens assays on diabetic and galactosemic rats receiving diets that modify cataract development. Invest Ophthalmol Visual Sci 4: 98-103

2. Hutton JC, Schofield, PJ, Williams JF, Regtop HL, Hollows FC (1976) The effect of an unsaturated-fat diet on cataract formation in streptozotocin-induced diabetic rats. $\mathrm{Br} J$ Nutr 36: $161-177$

3. Huggett AStG, Nixon DA (1957) Enzymic determination of blood glucose. Biochem J 66: 12P

4. Beale RN, Croft D (1961) A sensitive method for the colorimetric determination of urea. J Clin Pathol 14: 418-424

5. Lowry OH, Rosebrough NJ, Farr AL, Randall RJ (1951) Protein measurement with the Folin phenol reagent. J Biol Chem 193: 265-275

6. Hatch MD, Shaio-Lim Mau (1973) Activity, location, and role of aspartate aminotransferase and alanine aminotransferase isoenzymes in leaves with $\mathrm{C}_{4}$ pathway photosynthesis. Arch Biochem Biophys 156: 195-206

7. Srere PA (1962) Citrate-cleavage enzyme. Methods Enzymol 5: $641-644$

8. Zalitis J (1976) Modification of native sheep liver fructose1,6-bisphosphatase by Subtilisin. Biochem Biophys Res Commun $70: 323-330$

9. Sharma C, Manjeshwar R, Weinhouse S (1963) Effects of diet and insulin on glucose-adenosine triphosphate phosphotransferases of rat liver. J Biol Chem 238: 3840-3845

10. Glock GE, McLean P (1953) Further studies on the properties and assay of glucose-6-phosphate dehydrogenase and 6-phosphogluconate dehydrogenase of rat liver. Biochem J 55: $400-408$

11. Yeung D, Stanley RS, Oliver IT (1967) Development of gluconeogenesis in neonatal rat liver. Effect of triamcinolone. Biochem J 105: 1219-1227

12. Ochoa S (1955) 'Malic' enzyme. Methods Enzymol 1: $739-740$

13. Ballard FJ, Hanson RW (1969) Purification of phosphoenolpyruvate carboxykinase from the cytosol fraction of rat liver 
and the immunochemical demonstration of differences between this enzyme and the mitochondrial phosphoenolpyruvate carboxykinase. J Biol Chem 244: 5625-5630

14. Irving MG, Williams JF (1973) Kinetic studies on the regulation of rabbit liver pyruvate kinase. Biochem J 131: 287-301

15. Freedland RA, Avery EH (1964) Studies on threonine and serine dehydrase. J Biol Chem 239: 3357-3360

16. Brown GW, Cohen PP (1959) Comparative biochemistry of urea synthesis. I. Methods for the quantitative assay of urea cycle enzymes in liver. J Biol Chem 234: 1769-1774

17. Duncan DB (1955) Multiple range and multiple $F$ tests. Biometrics 11: 1-42

18. Rosen F, Roberts NR, Nichol CA (1959) Glucocorticosteroids and transaminase activity. I. Increased activity of glutamicpyruvic transaminase in four conditions associated with gluconeogenesis. J Biol Chem 234: 476-480

19. Salas M, Vinuela E, Sols A (1963) Insulin-dependent synthesis of liver glucokinase in the rat. J Biol Chem 238: 3535-3538

20. Shrago E, Lardy HA, Nordlie RC, Foster DO (1963) Metabolic and hormonal control of phosphoenolpyruvate carboxykinase and malic enzyme in rat liver. J Biol Chem 238: 3188-3192

21. Takeda $Y$, Inoue $H$, Honjo $K$, Tanioka $H$, Daikuhara $Y$ (1967) Dietary response of various key enzymes related to glucose metabolism in normal and diabetic rat liver. Biochim Biophys Acta 136: 214-222

22. Wimhurst JM, Manchester KL (1970) A comparison of the effects of diabetes induced with either alloxan or streptozotocin and of starvation on the activities in rat liver of the key enzymes of gluconeogenesis. Biochem J 120: 95-103

23. Chang AY, Schneider DI (1971) Hepatic enzyme activities in streptozotocin-diabetic rats before and after insulin treatment. Diabetes 20: 71-77

24. Niemeyer H, Clark-Turri L, Garces E, Vergara FE (1962) Selective response of liver enzymes to the administration of different diets after fasting. Arch Biochem Biophys 98: 77-85

25. Suzuki H, Fuwa $H$ (1970) Influence of dietary composition on the capacity of glucose formation in liver of rats. Agr Biol Chem 34: 80-87
26. Akrabawi SS, Saegert MM, Salji JP (1974) Studies on the growth and changes in metabolism of rats fed on carbohydrate-deficient fatty acid-based diets supplemented with graded levels of maize starch. Br J Nutr 32: 209-217

27. Kopelovich L, Sabine JR (1970) Control of lipid metabolism in hepatomas: effects of fasting and dietary fat on the activities of several glycolytic and Krebs-cycle enzymes in mouse liver and hepatoma BW 7756. Biochim Biophys Acta 202: 269-276

28. Clarke SD, Romsos DR, Leveille GA (1977) Influence of dietary fatty acids on liver and adipose tissue lipogenesis and on liver metabolites in meal-fed rats. J Nutr 107: 1277-1287

29. Duck-Chong CG (1974) Ph. D. Thesis, Sydney University

30. Wiley JH, Leveille GA (1973) Metabolic consequences of dietary medium-chain triglycerides in the rat. J Nutr 103: $829-835$

31. Clarke SD, Romsos DR, Leveille GA (1977) Differential effects of dietary methyl esters of long-chain saturated and polyunsaturated fatty acids on rat liver and adipose tissue lipogenesis. J Nutr 107: 1170-1181

32. Tepperman H, Tepperman J (1965) Effect of saturated fat diets on rat liver NADP-linked enzymes. Am J Physiol 209: $773-780$

33. Benjamin W, Gellhorn A (1964) The effect of diabetes and insulin on the biosynthesis of individual fatty acids in adipose tissue. J Biol Chem 239: 64-69

Received: February 20, 1979, and in revised form: October 31,1979

Associate Professor P. J. Schofield

School of Biochemistry

University of New South Wales

Kensington, N. S. W. 2033

Australia 